\title{
Can the morality of a group whose members are interdependent be extended to all humanity and beyond?
}

Egbert Giles Leigh Jr. * (D)

\begin{abstract}
I review David Sloan Wilson's This View of Life, which considers why a group's members, if tightly interdependent, must treat each other sympathetically, justly and generously, and what actions could cause these sentiments to extend to all humanity.
\end{abstract}

Keywords: Social groups, Selection among groups, Interdependence, Cultural evolution, Natural selection, Multilevel selection, Units of selection, Morality, Core design principles

\section{Book details}

Title

ISBN

Number of pages

Author

Published by
This View of Life: Completing the Darwinian Revolution 9781101870204

xiv +286

David Sloan Wilson

New York: Pantheon Books; 2019, $\mathrm{H} / \mathrm{b} \$ 36.95$

\section{Book review}

"No tribe could hold together if robbery, murder, treachery, Ec, were common; consequently such crimes within the limits of the same tribe 'are branded with everlasting infamy;' but excite no such sentiment beyond these limits." (Darwin 1871, p. 97).

"... a tribe including many members who, from possessing in a high degree the spirit of patriotism, fidelity, obedience, courage, and sympathy were always

*Correspondence: bufotyphonius@gmail.com Baltimore, MD, USA ready to give aid to each other and to sacrifice themselves for the common good, would be victorious over most other tribes; and this would be natural selection." (Darwin 1871, p. 166).

"... as man gradually advanced in intellectual power and was enabled to trace the more remote consequences of his action;... as from habit, following on beneficial experience, instruction and example, his sympathies become more tender and widely defused, so as to extend to all races,... and finally to the lower animals, - so would the standard of his morality rise higher and higher." (Darwin 1871, p. 103).

In This View of Life, David Sloan Wilson has two goals. First, he seeks (successfully) to show what conditions favor the development of moral sentiments that elicit cooperation within small groups. Then he suggests how these sentiments can be extended from fellow group members to all humanity. In this project, Wilson is guided by Dobzhansky's dictum (pp. 5-6): "Nothing in biology makes sense except in the light of evolution."

Wilson's second goal is particularly vital for a world so riven by dissension and hatred. He does not achieve this goal. Nonetheless, he has a great deal to say relevant to

(c) The Author(s) 2019. This article is licensed under a Creative Commons Attribution 4.0 International License, which permits use, sharing, adaptation, distribution and reproduction in any medium or format, as long as you give appropriate credit to the original author(s) and the source, provide a link to the Creative Commons licence, and indicate if changes were made. The images or other third party material in this article are included in the article's Creative Commons licence, unless indicated otherwise in a credit line to the material. If material is not included in the article's Creative Commons licence and your intended use is not permitted by statutory regulation or exceeds the permitted use, you will need to obtain permission directly from the copyright holder. To view a copy of this licence, visit http://creativeco mmons.org/licenses/by/4.0/. The Creative Commons Public Domain Dedication waiver (http://creativecommons.org/publicdomain/ zero/1.0/) applies to the data made available in this article, unless otherwise stated in a credit line to the data. 
it which should be read, learned and inwardly digested. Readers must not let Wilson's semantics deter them.

Others before him have asked similar questions. Darwin (1871: see first two epigraphs) provided a sound evolutionary answer to the first question. It is much sounder than E. O. Wilson's (1975) because Darwin (1871, pp. 97-98) recognized that human beings are not innately wholly selfish, but have inherited social sympathies from their social ancestors. Darwin (1871), pp. 165-166) clearly understood the concept of cultural evolution, even if he did not name it, whereas E. O. Wilson started from selfish genes and ignored cultural inheritance, an approach that works far better for hymenoptera than primates. Following Darwin, Changeux and Ricoeur (2000) and Changeux (2008) asked whether, and if so how, natural selection could establish neurological predispositions for a universal ethics. On the humanistic side, Plato's (Republic, Book I, 351c-e) gang of thieves, whose interdependent members must treat each other fairly for the gang to succeed or even survive, anticipates Darwin's tribe of interdependent hunter-gatherers by two millenia. Adam Smith (1776) shows how competition prompts cooperation: some individuals must form cooperative groups to compete successfully with powerful others. Both Plato and Adam Smith argued from the consequences of behaviors, so their arguments can be phrased in terms of natural selection. Indeed, a coherent theory of natural selection may provide the best means for distinguishing valid from invalid consequentialist arguments.

How to extend a person's sympathy beyond fellow group members is a far more difficult problem. As Darwin (1871, p. 103; see 3rd epigraph) pointed out, extending sympathy involves transforming culture. Changeux and Ricoeur (2000) recount experiments and observations suggesting inborn elements of sympathy and morality. Babies $>18$ months old seek to comfort other babies they hear crying (Changeux 2008, p. 50). Like other social animals such as wolves, a normal child 4-7 years old ceases hurting another when it cries or shows other signs of distress (Changeux and Ricoeur 2000 , p. 217, a behavior called "violence inhibition" (Changeux 2008). Changeux (2008, p. 95) thinks violence inhibition may be the biological foundation of moral sensitivity. When $\sim 4$ years old, children develop a "theory of mind," enabling them to see things from another's standpoint (Changeux 2008, p. 54), which enables greater refinement of moral behavior. Elliot Turiel found that Amish Mennonite and Orthodox Jewish children distinguish conventions binding only on members of their own communities from universal moral rules of justice and fairness forbidding theft, slander, vandalism etc. (Changeux and Ricoeur 2000, p. 234; Changeux 2008 p. 54). Darwin (1871, p. 106) thought the Golden Rule, "As ye would that men should do to you, do ye to them likewise," the logical outcome of social instincts in intelligent animals. Changeux (2008, p. 44) emphasizes this rule's universality. Yet the world is riven by strife, and "populist" leaders win elections by promising to halt cooperation with other nations.

How does Wilson deal with these problems? He begins by disposing of "social Darwinism," which Spencer invented before 1859, and Darwin never endorsed (Changeux 2008, p. 66). Spencer did not believe in helping the poor (Changeux 2008, p. 68), whereas Darwin (1871, p. 103) desired to extend sympathy to all humanity. Spencer treated societies as superorganisms (Changeux 2008, pp. 67-68), but knew not what holds societies together.

Wilson (pp. 40-49) also criticizes other pre-evolutionary predecessors, less justly. Adam Smith (1759, Part II, Section II, Chapter II, 1) knew perfectly well that competition was likely to benefit society only if society enforced rules of fairness, even if Smith (1776) did not foresee tragedies of the commons (Hardin 1968). Plato stated the crucial role of interdependence in promoting within-group morality more clearly than Wilson. In complete ignorance of evolution, the 1527 Schleitheim Confession proposed Ostrom-like (pp. 105-110) core design principles for Anabaptist congregations (see below). Understanding human nature is more important for effective social planning than understanding evolution: too many "neo-Darwinists" forget that human beings are born social (Midgley 2010), a rather inhuman error. In defending Darwin's predecessors, however, I have no desire to deny the importance of establishing an evolutionary foundation for a good understanding of human nature.

Wilson (p. 68) then promotes four pillars of a trait's evolutionary explanation: function (what gives it selective advantage); history (the stages by which the trait evolved); mechanism (how the trait works); and how it develops from egg to adult (Tinbergen 1963). These factors must be considered in tackling social problems. For example, eye development depends on the correct timing of environmental stimuli. Doctors delayed operating on babies born with cataracts until they learned that cataracts blocked the light newborns need to stimulate normal eye development: delaying their removal caused the same impairment of vision as never removing them (p. 54). Similarly, children must be exposed to dirt, as everyone was before 1900 , for their immune systems to develop properly (pp. 58-65). Overcleanliness multiplies allergies. Finally, trying to teach children how to read or write before they have adequate experience of the play required to develop social skills, such as most children 
in our evolutionary past enjoyed, actually hinders future academic development (pp. 68-72).

Wilson then turns to within-group morality A quiz on defining goodness Wilson (pp. 76-77) gives whenever he can, reveals that in a very multicultural society people agree remarkably on what qualities reflect goodness. Likewise, C. S. Lewis (1952, p. 19) commented on the great similarity in different cultures' moral codes. Changeux (2008, p. 44) and Boehm (2012, pp. 49-50) remark the worldwide prevalence of the "golden rule," which Darwin (1871, p. 165) called "the foundation of morality." How could such morality evolve? Like Darwin (1871, pp. 162-163), Wilson (p. 78) says that within groups selfishness tends to replace cooperativeness, but groups of cooperative individuals replace groups of selfish ones. He concludes that selection among groups must have driven the evolution of morality. Wilson (pp. 84-87) illustrates the contrast by citing egg production by hens crowded all their lives in cages of eight apiece. Those who lay the most eggs in their groups aggressively hog resources to do so. Thus eight young of "champion" egg-layers placed in one cage hurt each other and lay few eggs. If, however, one populates new cages with young of hens from cages producing the most eggs, egg production per cage increases, because these hens do not interfere with one another.

Cooperative groups, however, evolve only if each group's members depend on each other to live and reproduce (Darwin 1871, pp. 78-79), for only then must they treat each other fairly and justly to ensure the cooperation they need to survive, as in Plato's (Republic, Book I, $351 \mathrm{c}-\mathrm{e})$ gang of mutually interdependent thieves. Wilson, however, is slow to emphasize the importance of interdependence.

Wilson (p. 90) concludes that human within-group morality evolved when selection among groups replaced within-group selection as the main driver of adaptation. Selection among groups, however, must be truly ferocious to override significant within-group selection (Leigh 1983). Interdependence among a group's members must be really tight for group selection to prevail. Darwin's (1871, p. 96) observation, however, that the morality of hunter-gatherer tribes is geared entirely to suit the tribe's, not the individual's or all humanity's, good suggests that group selection drove the evolution of tribal morality.

Interdependence once drove the evolution of a moral rule among macromolecules. None of an individual's notoriously selfish genes (Dawkins 1976) can reproduce unless its fellow genes all do their jobs properly. Selection thus favors fair meiosis, which ensures that a new allele spreads only if it benefits its genome (Leigh 2010, p. 10). The fairness of meiosis is thus a moral rule that serves the common good of the genome's genes (Leigh and Ziegler 2019, pp. 148-151), assuring equal reproductive success for them all, as rules of fairness are needed to make competition likely to benefit human society (Smith 1759, 1776).

Wilson (p. 89) cites two other cases where selection among groups replaced within group selection as the driver of adaptation. Both represent "major evolutionary transitions" (Maynard Smith and Szathmáry (1995). The first is the evolution of metazoans. These must have originated as clonal clumps, each arising from a single, sexually produced cell. A clump's cells are genetically identical, but each clump's genotype is unique. Once cells can no longer move to other clumps, only groups offer variation for selection to choose from (Leigh 1991). The second is the evolution of honeybees. Because a queen mates multiply and mixes her sperm thoroughly, kin selection generates a common interest among the workers in allowing only their unique queen to reproduce, and helping her do so (Seeley 1995). This circumstance leaves no scope for intragroup selection: only selection among colonies shapes adaptation (Fisher 1930, p. 187; Seeley 1997; Gardner and Grafen 2009). In both cases, ferocious suppression of within-group selection ensures that cooperation reigns supreme within the organism or superorganism, for whose good group members have become automata. There is no place for morality here.

Indeed, if intelligence lacks, truly Draconian measures are needed to assure cooperation among interdependent group members. Two or three pairs of greater anis, Crotophaga major, lay eggs in the same nest, jointly defend the nest and its eggs, and jointly defend and feed the nestlings (Riehl and Jara 2009), because single pairs cannot defend their nests from predators or competitors. To ensure cooperation, they equalize each pair's reproductive output. Each female ejects eggs from the nest until she lays one. Once all have laid, they lay in rotation, and cease laying simultaneously, leaving each pair with the same number of eggs to be incubated. This system works because anis cannot distinguish their own eggs or nestlings. But egg ejection costs. Although three or four pairs defend a nest better than two, any asynchrony in readiness to lay causes so many eggs to be ejected from 3-and especially 4-pair nests that the anis abandon the nest before all have laid, perhaps forfeiting that season's reproduction (Riehl 2010, 2011, 2016).

Wilson's primary contribution is showing how cultural evolution "paves the way" for group selection. Darwin (1871, p. 164) showed how a culture that confers good reputation on moral behavior helps spread morality within groups. Elinor Ostrom's core design principles for making groups effective (pp. 117-123) show how culture can shape truly cooperative groups. These principles 
are: 1 . A group must have a clearly defined membership and a mutually agreed purpose that members consider urgent; 2. Members should benefit according to their contribution to the group's goals; 3. Decision-making should be fair and inclusive; 4 . Compliance with a mutually agreed code of behavior should be monitored; 5 . Breaches thereof should be sanctioned according to the severity and the frequency of the offense; and 6. Fast and fair conflict resolution. These principles summarize Boehm's $(1997,2012)$ account of morality in hunter-gatherer tribes. Groups within larger societies 7. must also have enough autonomy to manage their own affairs properly, and 8. a group must maintain good relations with fellow groups (often not true for hunter-gatherer tribes).

Ostrom's principles make many groups wonderfully effective. They prevent tragedies of the commons (Hardin 1968) among a Turkish city's fishermen (p. 116) and Maine lobstermen (p. 118). They enable residents of a rundown inner-city block to help each other improve the quality of life on their block (pp. 132-134) and previously failing children in an inner-city school to improve their behavior enough that teachers can teach, not just enforce order (pp. 123-132). They enable "rapid response" teams modelled on emergency response teams to make their business more profitable and more satisfying to work for (pp. 208-211). The Anabaptist 1527 Schleitheim Confession (Yoder 1977) created congregations with clearly defined goals, whose members were carefully enough trained and tested to be baptized; rules were clear, and enforced by appropriately graded sanctions; decisionmaking was communal; and their mutually supportive behavior was modelled on the New Testament. These principles enabled Anabaptists to survive vicious and prolonged persecutions. Although proven wonderfully effective, Ostrom's principles have been slow to catch on. They have not been tried and found wanting: all too often, they have offended the vanity of micromanaging bosses and not tried.

Modern groups must be able to adapt to accelerating social change. One way to achieve this is organizing within-lifetime "variation-selection systems" like trial and error learning (pp. 199-201). For example, in Toyota's assembly line (pp. 201-208) workers signal when problems arise, attracting supervisors who discuss possible solutions with them, which are then tested to learn which is best. In "innovation oases" like Silicon Valley and Israel (pp. 211-215), groups of truly imaginative people with diverse skills, who trust and are generous to each other, pool their skills to invent new products which are then tested for marketability. Their interactions enable them to detect and exclude "bad actors," but a group of innovators is open to all with something to contribute. Wilson concludes that within-business reforms make selection among firms more effective, and the economy more adaptable.

The core design principles governing hunter-gatherer tribes, and perhaps 16th century Anabaptist congregations, enable genetic selection among groups. In most human groups, ranging from inner city classrooms to emergency response teams, members belong for only parts of their lives. True, belonging to these other groups, if they are effective, can bring emotional satisfaction, that can arise from causes as distinct as unexpected success in school, better understanding of what is taught, appreciation by others for a job well done, or a sense of benefitting others, either neighbors or the world at large. Such satisfaction often improves health and therefore individual fitness. A person, however, can belong to many different groups, each with a different set, and often a different geographic range, of members. It is not clear that "multilevel selection" is a useful tool for analyzing the impact of limited-time group membership on cultural evolution in complex modern societies equipped with radio, television and internet. What Pascal (1976, Pensée 1) called "l'esprit géometrique", which can draw exact conclusions from a few clearly defined axioms (however unintuitive), is well suited to studying two-level selection (Wilson 1975, 1980; Leigh 1983). But the swarm of variables involved in studying cultural evolution in complex modern societies completely defeats "l'esprit géometrique." The surest guide here is the empirical good sense and human understanding of an Elinor Ostrom.

The next chapter's title, "From groups to individuals," proclaims that the group is the primary unit of selection in human beings. Wilson (pp. 145-146) tries to dismantle the concept of human individuality by observing that a human being is the product of social interactions with those who brought her up or grew up with her (human beings must be brought up in a social setting to express their genetic potential). This is quite true-as indigenous Amazonian tribes recognize (Guzmán-Gallegos 2015, p. 127). Chimpanzees are also "social constructs," who live only in groups, but their groups are too large and withingroup interdependence too diffuse, for these groups to be primary units of selection. A Paramecium can only live in some ecosystem, but it, not its ecosystem, is a unit of selection, even though ecosystems are in some respects functional units (Leigh and Vermeij 2002).

Human groups did live in small hunter-gatherer tribes, primary units of selection, for many tens of thousands of years, a circumstance that left many traces in modern human behavior. We are adapted to face crises, not alone, but in the company of supportive others, and we cope better when so accompanied (p. 152). Even holding the hand of a spouse or close friend instils confidence (pp. 146-153, de Waal 2019, pp. 233-234). Measures that help 
African-American students feel that they truly belong to their college community markedly improve their academic performance (pp. 166-167). Social traces of the hunter-gatherer past are even clearer in indigenous Amazonian tribes, which have a far more communal sense of wellbeing than that prevailing in the US (SantosGranero 2015). They believe that people must work hard, not to accumulate goods for themselves, but to produce goods to share with others, and that they must join in joyful communal festivals, thereby ensuring that there is plenty of food to share in a community blessed with happy, mutually supportive relationships. In their view, a human being is rightly reared by suppressing antisocial emotions such as anger, jealousy and stinginess, encouraging love, happiness and sympathy, instilling an ethic of hard work to produce goods to share, and caring for and about others of their tribe (Barletti 2015, p. 142). These tribes are rather egalitarian, and their members dislike those who accumulate goods without sharing (SantosGranero 2015, p. 29). These traits all reflect the morality of their hunter-gatherer ancestors.

Nowadays, conflictual relationships characterize many families. Here, self-regarding hostility begets self-regarding hostility, often for generations (p. 158). Some organizations seek to recreate the tribal ambiance where the child is surrounded by supportive adults by persuading parents to apply Ostrom's core design principles to family behavior-abundant rewards for good behavior, mild but escalating sanctions for bad (p. 159-160). Applying these principles works. But in hunter-gatherer days, selection among tribes eliminated dysfunctional families: now we must arrange for cultural change to make families functional. What happened?

Today, few human groups are primary units of selection. The spread of agriculture, with its production of storable goods, has caused tribes to coalesce or be forced into larger societies. These societies have become more hierarchical, and division of resources within them much less equal, giving rise to social conflicts that sometimes force emigration. These tensions are most easily palliated by wars with other societies. During the last few centuries, some societies have modernized, multiplying opportunities for emigration, which weakens interdependence within neighborhoods and can create "neighborhoods" of total strangers. More recently, opportunities for emigration have also loosened interdependence within families and multiplied single-parent families. Ostrom (2007) thought that Maine lobstermen could readily agree on how to resolve a tragedy of the commons, because their families had known each other for generations, giving rise to mutual trust: in modern societies, few neighborhoods are so stable. Modernization, which destabilizes neighborhoods and often generates gross inequalities, has bequeathed new tensions within neighborhoods and families, in addition to the tensions between larger units that have always been with us. Wilson outlines reasonable ways to reduce tensions within neighborhoods and families: will people accept his remedies?

The book's last quarter considers how to extend morality beyond small groups. Since selection among groups led to metazoans, functional individuals with trillions of cells which cooperate for their individual's good, Wilson (pp. 173-174) argues that multilevel selection can extend morality to large human groups. Regulation is needed to suppress disruptively selfish behavior within nearly all cooperative associations, including metazoans. One must, however, understand how cooperation in a social group works to regulate it properly (p. 194). Shame (pp. 178-179) is one regulatory mechanism-in groups whose members agree on what is right.

Nations vary in how well they serve their people's common good (pp. 185-193). A nation's income inequality is correlated with its prevalence of ill health and social tension (p. 186). When income inequality and social tension peaked in the US in 1900, many of its wealthiest people began plowing wealth into improving living conditions and opening opportunities for the poor (pp. 191-192), initiating a decline in social tension and degree of illhealth that only bottomed out in 1960. Struggles with other countries sometimes prompt such reforms, as war with Prussia prompted Maria Theresa's social reforms in Austria (Judson 2018), but in the US, social reform was prompted by wealthy people acting to preserve the society on which they depended. Restoring the health of $U$. S. society was driven by some of its members' sense of community. How does one awaken a sense of community among a nation's people?

Wilson suggests joining beneficial groups, and using core design principles to make them more effective and spread their benefits more widely. He praises an agricultural "ecovillage" where newcomers must sign a comprehensive covenant meant to ensure that they live sustainably (p. 225): the covenant is so comprehensive because living sustainably involves so many different factors. This village's per capita electricity use is $82 \%$, water use is $92 \%(!)$ and solid waste production is $93 \%$ below the national average. The villagers work hard but live happily on an average family cash income of $\$ 10,000 / y$. A traditional Chinese peasant would envy their life. More such villages would be a very good thing. Nonetheless, basing all our agriculture on such villages would restore the land, but ruin the US economy and social structure. There would be too little exchange between these villages and non-agricultural sectors to support very much of the latter. Where would the money come from to support 
Wilson's book, him, his family, and the research/teaching community on which such scientists depend?

Wilson's argument is based on the need for multilevel evolutionary biology to guide us toward a sound universal morality (pp. 218-211). Biology does tell us that morality evolves in small groups whose members depend on each other to survive. Understanding human nature, however, matters even more-for example, it lets us see that abundant play is needed for a child to mature properly. Moreover, Wilson's desire to transform all humanity into a "superorganism" (p. 221) will repel many. Would those who wrote the US Bill of Rights or the French Declaration of the Rights of Man willingly become analogues of cells in metazoans, cogs whose only purpose is to serve the good of the whole? The French novelist Bernanos (1953) warned against the "depersonalization" that results from too great a victory of the collective over the individual. Perhaps Wilson understands the word "superorganism" differently from others. Earlier, his redefinition of "group selection" caused endless controversy (Leigh 2010, pp. 13-15). Misusing the word "superorganism" could destroy the effectiveness of this important book. After all, the "innovation oases" Wilson discusses depend on firms striking the right balance between their goals and their members' initiatives. Although the US is now suffering from an overdose of competitive individualism, valuing individuals and their desires was a crucial achievement of the Enlightenment (Midgley 2010).

Wilson (pp. 222-224) infers from evolutionary theory that the whole earth's welfare must be our goal, and that regulation is needed to suppress disruptive selfish behavior. If we agree that disruptively selfish behavior is undesirable, the second is scientific fact, but the first is beyond the reach of unaided science, even if science can help us achieve that goal, once we adopt it.

Wilson (p. 223) also argues that people agree on an ethic directed toward the common good of humanity and the health of the earth's biota. Agreement, however, dissolves over what sacrifices are worth making to achieve this end. Moreover, ever more politicians win elections by aggressively putting their nation, or some subgroup of it, first. Wilson focuses on effective action. But how do we motivate active care for the whole earth? Perhaps Wilson's emphasis on effective action explains why he says much less than Changeux and Ricoeur (2000) or Nussbaum (2015) about possible ways religion can help broaden a sense of community, even though he recognizes that the most deeply religious have the most expansive love of humanity and are friendliest to those of other religions (p. 223). Unlike Changeux and Ricoeur (2000), Wilson does not ask how religious symbolism can develop a sense of community. Fortunately, Wilson shows no interest in civic religion which, even as conceived by Rousseau and Comte, poses a serious threat to freedom of thought (Nussbaum 2015, pp. 44-46, 57-69).

Nussbaum (2015), like Abraham Lincoln, Franklin Roosevelt and Martin Luther King, Jr., focused on arousing emotions that stimulate right action by arousing the nation's sense of community. These emotions must extend beyond concern and duty to genuine love, what the Greeks called agapé (Nussbaum 2015; Friedmann 2017). The rhetoric of Lincoln, Roosevelt and King expanded the nation's sense of community, at least for a while. This sense is effective only if we cultivate "theory of mind" - the ability to see the world as others see it. Here, public education has a crucial role to play. Theory of mind is cultivated by reading literary fiction (Kidd and Castano 2013), participating in drama and musical ensembles (Nussbaum 2015) and viewing works of art (Changeux 2008). The current belief among school and college administrators that science is the only profitable way of knowing has forced the elimination of "frivolities" such as music, drama and art from school curricula. This most dehumanizing "reform" poses a real threat to what is left of the sense of community in the U. S.

In sum, it is easy to criticize Wilson for not getting us very far towards a believable, practical, universal morality. His goal, however, is vital, the task is diffcult, and he provides many ideas about good actions to take. Finding the road to a universal morality, however, depends on understanding, and dealing with, why modern society is a "universal social solvent" (Levy 1966). Contact with modern society erodes the belief structures of traditional societies: the emphasis of modern societies on competitive acquisitiveness of individuals threatens the communal sense of wellbeing of Amazonian tribes (Santos-Granero 2015). More immediately, the ice caps of Greenland and Antarctica are melting away, raising sea level, while politicians try to block measures that would save the world's coasts. Can a sense of community, a love of our fellows around the world, sufficient to address this problem before we perish in some night of hate and war as the rising sea slowly drowns the world's most populous cities?

\section{Acknowledgements \\ The author is most grateful to Revati Gireesh for her guidance through the process of electronic submission.}

\section{Authors' contributions}

EL read the book and wrote the book review. The author read and approved the final manuscript.

Funding

The author received no funding for preparing this book review.

Availability of data and materials Not applicable. 


\section{Competing interests}

The author declares no competing interests.

Received: 27 October 2019 Accepted: 11 December 2019

Published online: 19 December 2019

\section{References}

Barletti JPS. "It makes me sad when they say we are poor: we are rich!" Of wealth and public wealth(s) in indigenous Amazonia. In: Santos-Granero F, editor. Images of public wealth or the anatomy of well-being in indigenous Arizona. Tucson: University of Arizona Press; 2015. p. 139-60.

Bernanos G. La liberté pour quoi faire? In: Bernanos G, editor. La liberté pour quoi faire?. Paris: Gallimard; 1953. p. 75-118.

Boehm C. Impact of the human egalitarian syndrome on Darwinian selection mechanics. Am Nat. 1997;122:S100-22.

Boehm C. Moral origins: the evolution of virtue, altruism and shame. New York: Basic Books; 2012.

Changeux J-P. Du vrai, du bien, du beau. Paris: Odile Jacob; 2008.

Changeux J-P, Ricoeur P. What makes us think?. Princeton: Princeton University Press; 2000

Darwin C. The descent of man, and selection in relation to sex. London: John Murray; 1871

Dawkins R. The selfish gene. Oxford: Oxford University Press; 1976.

de Waal FBM. Mama's last hug. New York: Norton; 2019.

Fisher RA. The genetical theory of natural selection. Oxford: Clarendon Press; 1930.

Friedmann R. Design for living: Regard, concern, service, and love. Eugene: Wipf and Stock; 2017.

Gardner A, Grafen A. Capturing the superorganism: a formal theory of group adaptation. J Evol Biol. 2009;22:659-73.

Guzmán-Gallegos MA. Amazonian Kichwa leadership: the circulation of wealth and the ambiguities of mediation. In: Santos-Granero F, editor. Images of public wealth or the anatomy of well-being in indigenous Amazonia. Tucson: University of Arizona Press; 2015. p. 117-38.

Hardin G. The tragedy of the commons. Science. 1968;152:1243-8.

Judson P. The Habsburg Empire: a new history. Cambridge: Belknap Press; 2018.

Kidd DC, Castano E. Reading literary fiction improves theory of mind. Science 2013;342:377-80.

Leigh EG Jr. When does the good of the group override the advantage of the individual? PNAS. 1983;80:2985-9.

Leigh EG Jr. Genes, bees and ecosystems: the evolution of a common interest among individuals. Trends Ecol Evol. 1991;6:257-62.

Leigh EG Jr. The group selection controversy. J Evol Biol. 2010;23:6-19.
Leigh EG Jr, Vermeij GJ. Does natural selection organize ecosystems for the maintenance of high diversity and productivity? Phil Trans R Soc Lond B. 2002:357:709-18.

Leigh EG Jr, Ziegler C. Nature strange and beautiful: how living beings evolved and made the earth a home. New Haven: Yale University Press; 2019.

Levy MJ Jr. Modernization and the structure of societies. Princeton: Princeton University Press; 1966.

Lewis CS. Mere christianity. New York: MacMillan; 1952.

Maynard Smith J, Szathmáry E. The major transitions in evolution. Oxford: Freeman/Spektrum; 1995.

Midgley M. The solitary self. Durham: Acumen; 2010.

Nussbaum MC. Political emotions: why love matters for justice. Cambridge: Harvard University Press; 2015.

Ostrom E. A diagnostic approach to going beyond panaceas. PNAS. 2007;104:15181-7.

Pascal B. Pensées. Paris: GF-Flammarion; 1976

Riehl C. Egg ejection risk and hatching asynchrony predict egg mass in a communally breeding cuckoo, the Greater Ani (Crotophaga major). Behav Ecol. 2010;21:676-83.

Riehl C. Living with strangers: direct benefits favour non-kin cooperation in a communally nesting bird. Proc R Soc B. 2011;278:1728-35.

Riehl C. Infanticide and within-clutch competition select for reproductive synchrony in a cooperative bird. Evolution. 2016;70:1760-9.

Riehl C, Jara L. Natural history and reproductive biology of the communally breeding greater ani (Crotophaga major) in Gatun Lake, Panama. Wilson J Ornithol. 2009;121:677-87.

Santos-Granero F. Introduction. In: Santos-Granero F, editor. Images of public wealth, or the anatomy of well-being in indigenous Amazonia. Tucson: University of Arizona Press; 2015. p. 3-34.

Seeley TD. The wisdom of the hive. Cambridge: Harvard University Press; 1995.

Seeley TD. Honey bee colonies are group level adaptive units. Am Nat. 1997; 150:\$22-41.

Smith A. The theory of moral sentiments. London: A. Millar; 1759.

Smith A. An inquiry into the nature and causes of the wealth of nations. London: Strahan and Cadell; 1776.

Tinbergen N. On aims and methods of ethology. Z Tierpsychol. 1963;20:410-35.

Wilson DS. A theory of group selection. PNAS. 1975;72:143-6.

Wilson DS. The natural selection of populations and communities. Menlo Park: Benjamin/Cummings; 1980.

Yoder JH. The Schleitheim confession. Scottdale: Herald Press; 1977.

\section{Publisher's Note}

Springer Nature remains neutral with regard to jurisdictional claims in published maps and institutional affiliations.
Ready to submit your research? Choose BMC and benefit from:

- fast, convenient online submission

- thorough peer review by experienced researchers in your field

- rapid publication on acceptance

- support for research data, including large and complex data types

- gold Open Access which fosters wider collaboration and increased citations

- maximum visibility for your research: over 100M website views per year

At BMC, research is always in progress.

Learn more biomedcentral.com/submissions 